\title{
Thermal Conversion of Terminalia catappa Wood using Ni/NZA Catalyst to Produce pyrolysis Oil
}

\author{
Syaiful Bahri ${ }^{1 *}$, Arbhy Indera Ikhwansyah ${ }^{1}$, Edy Saputra $^{1}$, Muhdarina $^{2}$ \\ ${ }^{1}$ Universitas Riau, Faculty of Engineering, Chemical Reaction Engineering Laboratory, \\ ${ }^{2}$ Universitas Riau, Faculty of Mathematics and Natural Sciences, Physical Chemistry Laboratory, \\ Kampus Bina Widya Jl. HR Subrantas Simpang Baru Pekanbaru 28293, Indonesia \\ ${ }^{*}$ Corresponding Author: sybahri2002[at]yahoo.co.uk
}

\begin{abstract}
Pyrolysis oil can be produced by pyrolysis of terminalia catappa wood using Ni/NZA catalyst. Objective of this research is to produce pyrolysis oil from terminalia catappa wood biomass as an alternative fuel, whille studying effect of weight ratio of catalyst Ni/NZA to biomass, effect of metal impregnation Nickel (Ni) on Natural Zeolite deAluminated (NZA) and characterization of physical and chemical properties of pyrolysis oil also studied. Process of pyrolysis was carried out in a pyrolysis reactor where 50 grams of biomass having + 100-200 mesh sieve size, various ratio of catalyst Ni/NZA to biomass weight of $2 \%$; $4 \%$ and $6 \%$ and $\mathrm{Ni}$ metal impregnated onto Natural Zeolite deAluminated (NZA) of 0\%; 1\%; $1.5 \%$ and $2 \%$ and a silinap 500 ml were well mixed at temperature of $320^{\circ} \mathrm{C}$ under flowing of Nitrogen and then organic vapour produced were allowed to flow to a condenser for condensation and measured as pyrolysis oil. From the results it was found the largest yield of oil was on the use of ratio catalyst Ni/NZA to biomass $4 \%$ having the metal content of $2 \%$ which is $68.22 \%$. Physical properties of pyrolysis oil was obtained density $0.806 \mathrm{~g} / \mathrm{ml}$, viscosity $7.591 \mathrm{cSt}$, acidity $74.078 \mathrm{mg} \mathrm{NaOH/g}$ sample, flash point $45.971{ }^{\circ} \mathrm{C}$ and calorific value $43.708 \mathrm{MJ} / \mathrm{kg}$ respectively. And then chemical analysis of pyrolysis oil using Gas Chromatography-Mass Spectroscopy (GCMS) was obtained several dominant chemical components such as acetic acid, 2-propanone, 1,2-ethanediol, propionic acid and methyl acetate respectively.
\end{abstract}

Keywords: Pyrolysis oil, Catalyst Ni/NZA, Pyrolysis, Terminalia Catappa wood

\section{Introduction}

Availability of petroleum as fuel resource cannot be renewed, while their usages for human needs as transportation fuel have tended to increase. So for that is inevitably needed an innovative energy conversion that does not rely on fossil resources which is a renewable that have an output similar to that generated from fossil fuel. Among that is pyrolysis oil which biomass based derived. It can be synthesized from biomass feedstock from various agricultural, industrial and household wastes. According to available data elsewhere, Indonesia has an abundant biomass potential, approximately 250 billion tones per year produced from forest and agricultural wastes, [1]. One of the potential sources of woody biomass is from Terminalia catappa, plant trees naturally spread in the tropic and subtropics regions, [2]. In producing of this oil from wood is used a pyrolysis process. In this process, organic matters of biomass undergo a heating treatment at a temperature between $450-600^{\circ} \mathrm{C}$ in absence of oxygen. As a result it produced organic vapors, gas and charcoal. Furthermore, the organic vapors are condensed to pyrolysis oil. It was reported in literature elsewhere that pyrolysis oil could be produced as much as $68 \%$ by weight of biomass, [3]. In aiming to accelerate the reaction in the pyrolysis process, presence of a catalyst is needed. The catalyst used in this study is a nickel metal supported on Natural Zeolite (NZ) support. Natural zeolite is selected as support due to its large enough abundant especially in Indonesia. This Natural Zeolite is modified to Natural Zeolite deAluminated (NZA) prior to use. The usage of natural zeolite as a catalyst is revealed in literatures elsewhere, [4]. In this research, Terminalia catappa wood is pyrolysed in a pyrolysis reactor into pyrolysis oil using catalysts $\mathrm{Ni} / \mathrm{NZA}$ having various variation of nickel metal content of $0,1,1.5$ and $2 \%$ in NZA support, while ratio of weight of catalyst
Ni/NZA to biomass (RWCB) is 2, 4 and 6\% respectively.

\section{Experimental}

\subsection{Materials}

Variations of metal nickel onto NZA is $0,1,1.5$ and $2 \%$ as previously stated, while the variation ratio of weight of catalyst $\mathrm{Ni} / \mathrm{NZA}$ to biomass is respectively 2,4 and $6 \%$ as also mentioned previously. In preparation, natural zeolite crushed in a porcelain mortar, then sieved to $-100+200$ mesh size. Furthermore, natural zeolite is dealuminated using $\mathrm{HCl} 6$ $\mathrm{N}$ and $\mathrm{NH}_{4} \mathrm{Cl} 1 \mathrm{~N}$ sequencially. For this aimed 200 grams of natural zeolite was refluxed in $1000 \mathrm{ml}$ of $\mathrm{HCl} 6 \mathrm{~N} 30$ minutes at temperature of $50^{\circ} \mathrm{C}$ while continously stirred in a flatbed reactor, then filtered and washed, and afterward cake is dried at a temperature $110^{\circ} \mathrm{C} 3$ hours. The cake, a sample, is then immersed again in $1000 \mathrm{ml} 1 \mathrm{~N} \mathrm{NH}_{4} \mathrm{Cl}$ solution at temperature of $90^{\circ} \mathrm{C}$ while stirred 3 hours a day for week to have natural zeolite dealuminated (NZA). The sample is then filtered and washed and then dried 24 hours at a temperature $110^{\circ} \mathrm{C}$. The next stage is impregnation of nickel metal onto NZA having variation $0,1,1.5$ and $2 \%$ by weight of NZA. The process began by suspending NZA into $100 \mathrm{ml}$ of $\mathrm{Ni}$ $\left(\mathrm{NO}_{3}\right)_{2} \cdot 6 \mathrm{H}_{2} \mathrm{O}$ and refluxed at $90^{\circ} \mathrm{C} 6$ hours while stirred in flatbed reactor. Then solution is dried at a temperature 110 ${ }^{\circ} \mathrm{C}$. At this stage is obtained catalyst Ni/NZA accordance to percentage of nickel metals impregnated. Furthermore, the catalyst $\mathrm{Ni} / \mathrm{NZA}$ was followed calcination, oxidation and reduction respectively for activation. In this aimed, the catalyst is inserted into tubular reactor as much as 40 grams. The tube was filled with porcelain bed as a heat homogenaized and between porcelain and catalyst bed glass woll was positioned. And then tube was placed vertically in a tube furnace, and then carried out calcination at temperature $500{ }^{\circ} \mathrm{C} 6$ hours in a flowed of nitrogen $400 \mathrm{ml} /$ minutes. Then

Volume 5 Issue 8, August 2016 www.ijsr.net 


\section{International Journal of Science and Research (IJSR) \\ ISSN (Online): 2319-7064}

Index Copernicus Value (2013): 6.14 | Impact Factor (2015): 6.391

followed, oxidation at temperature $400^{\circ} \mathrm{C}$ using oxygen 400 $\mathrm{ml} /$ minutes 2 hours and reduction at temperature $400^{\circ} \mathrm{C}$ using hydrogen $400 \mathrm{ml} /$ minutes 2 hours. Catalysts obtained were characterized for their physical characterization. On the other hand wood biomass was cut and dried in the sunrays, then crushed and further dried again in the sunrays. Then it sieved to obtain a size $-100+200$ mesh.

\subsection{Pyrolysis of biomass}

In this study, biomass of Terminalia catappa, as much as 50 grams, which having of particles size of $-100+200$ mesh and $500 \mathrm{ml}$ of thermo oil of silinap $280 \mathrm{M}$ is input into a pyrolysis reactor simultaneously. And then a pyrolysis process is conducted at temperature set of $320^{\circ} \mathrm{C}$, having pyrolysis time of 2 hours, and stirring speed of $300 \mathrm{rpm}$. This pyrolysis reactor is equipped with heating coil for heating process, and controled by a temperature controller. And then the reactor is connected to gas Nitrogen resources for innert gas flowing during process and then also connected to a condenser for condensation of the organic vapor produced during the process to produce liquid pyrolysis oil. This run is replicated to several runs for various variation of Nickel content on the catalyst and several ratio weight of catalyst to biomass of Terminalia catappa.

\section{Results and discussion}

\subsection{Effect variation of nickel metal (Ni) in Catalysts Ni/NZA to pyrolysis oil}

It seemed that impregnated metal nickel, $\mathrm{Ni}$ onto NZA affected yield of pyrolysis oil obtained from pyrolysis process of wood Terminalia catappa. Pyrolysis process was done by various variations of metals $\mathrm{Ni} 0,1,1.5 \%$ and $2 \%$ in catalyst $\mathrm{Ni} / \mathrm{NZA}$ as previously stated. In addition ratio weight of catalyst Ni/NZA to biomass, RWCB is 2,4 and $6 \%$ by weight respectively as also revealed previously. Result has given in several figures as followed.

As shown given in Figure (1 A), RWCB 2\%, (1 B), RWCB $4 \%$ and $(1 \mathrm{C})$, RWCB $6 \%$ respectively, it could be interpreted that more metal in catalyst NZA the greater yield of pyrolysis oil produced. This is might caused more metal contained in the catalyst surface NZA which increased surface area of the catalyst. And then surface area of catalyst will be governed activity of catalyst, hence more active phase available which then increased their activity on producing pyrolysed oil.

The highest yield obtained is of the catalyst Ni/NZA $2 \%$ weight of nickel metal and RWCB 4\% which is $68.22 \%$ and on the other hand the lowest yield obtained is on used of catalyst Ni/NZA having no metal loaded ( $0 \%$ by weight of the nickel metal mean no metal Ni content) and (RWCB) 2\% which is $44.77 \%$ respectively.
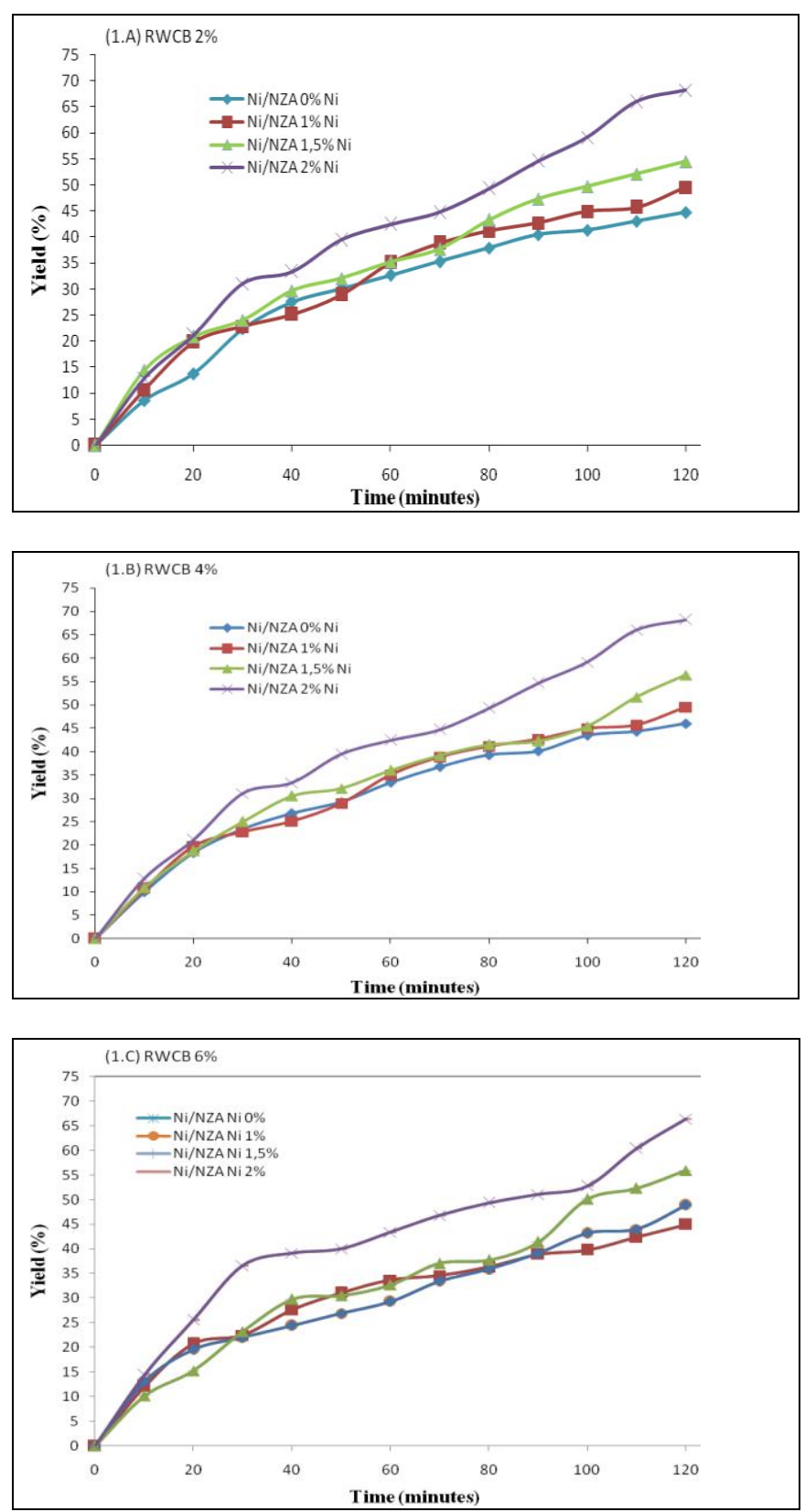

Figure 1: Pyrolysis oil on various variation of nickel metals on catalyst $\mathrm{Ni} / \mathrm{NZA}$ of $0,1,1,5$ and $2 \%$ for ratio weight of catalyst to biomass. (1 A), RWCB 2\%, (1 B), RWCB 4\% and (1 C), RWCB 6\%).

A probably a relatively large surface area available on catalyst $\mathrm{Ni} / \mathrm{NZA}$ which having metal content of $2 \%$ might due to presence of metal nickel, Ni on the surface of catalyst evenly dispersed. Setyawan and Handoko [5] explained that active metal impregnated on surface of support NZA is greatly affected surface area. Having a greater surface area of catalyst the greater the contact between catalyst should be, so that product formed will be greater, in this case yield of pyrolysis oil began to experience a significant increased in used of catalyst Ni/NZA $2 \%$. It can be concluded that more active metals are impregnated to support gived surface area of catalyst would be greater, hence catalyst activity would be increased and produced greater yield of product of pyrolysis oil. 


\section{International Journal of Science and Research (IJSR) \\ ISSN (Online): 2319-7064}

Index Copernicus Value (2013): 6.14 | Impact Factor (2015): 6.391

\subsection{Effect of weight variation of catalyst $\mathrm{Ni} / \mathrm{NZA}$ to} pyrolysis oil

From figure, (1A), RWCB 2\%, (1B), RWCB 4\% and (1C), RWCB 6\%) showed yield of pyrolysis oil in used of catalyst $\mathrm{Ni} / \mathrm{NZA}$ on various $\mathrm{Ni}$ content to weight ratio 2,4 and $6 \%$ to biomass. It seemed yeild increases as RWCB increased. This result were similar to result reported elsewhere [7] stated that greater concentration of catalyst more easily decomposition of cellulose in raw materials converted into pyrolysis oil. The more catalyst used, it will increase surface area of catalyst $\mathrm{Ni} / \mathrm{NZA}$. But in this study, yield of pyrolysis oil that produced on the use of catalyst Ni/NZA, RWCB $6 \mathrm{wt} \%$ were found declined. This might be due to use of catalyst Ni/NZA, RWCB $6 \%$ will might be produced a non-condensable gas phase greater than condensed phase. Result reported [7] explained that decline in yield of pyrolysis oil could be caused due to excess amount of catalyst that resulted in termination reaction of $\mathrm{C}-\mathrm{C}$ and $\mathrm{C}-\mathrm{H}$ bonds by metal nickel, $\mathrm{Ni}$ occured in high reaction speed. The higher metal nickel, $\mathrm{Ni}$ will be leaded to a growing number of $\mathrm{C}-\mathrm{C}$ bonds and $\mathrm{C}-\mathrm{H}$ are disconnected and caused more hydrocarbon fractions of short chains are formed and they can not be condensed in the condenser, so that yield of pyrolysis oil resulted into smaller amount and part of gases thouse could not be condensed were greater enough amount. The report revealed by reseacher [7] which stated that more amount of catalyst used will be produced a yield of pyrolysis oil that is increasingly it seemed remained unproven, but because of amount of catalyst increases, accumulated amount of metal nickel, $\mathrm{Ni}$ will be greater, which is why more uncondensed gases are formed.

\subsection{Characterization of Pyrolysis oil}

\subsubsection{Physical Analysis of Pyrolysis oil}

Physical properties of pyrolysis oil are involved measuring several parameters such as of density, viscosity, acidity and caloric value respectively. The physical properties of pyrolysis oil from this study compared to pyrolysis oil given by reaseacher elsewhere [8] is presented in Table 1 as followed.

Table 1: Comparison of physical characteristics of pyrolysis oil to pyrolysis oil of Mohan

\begin{tabular}{|c|c|c|}
\hline Parameters & $\begin{array}{c}\text { Pyrolysis oil from } \\
\text { this study (average) }\end{array}$ & $\begin{array}{c}\text { Pyrolysis oil } \\
{[8]}\end{array}$ \\
\hline Density (gram/ml) & 0.806 & $0.94-1.21$ \\
\hline Viscosity (cSt) & 7.591 & $15-35$ \\
\hline $\begin{array}{c}\text { Acid Value, } \mathrm{mg} \\
\text { NaOH/gram of } \\
\text { sampel }\end{array}$ & 74.078 & $35.1-50$ \\
\hline $\begin{array}{c}\text { Calorific Value } \\
(\mathrm{MJ} / \mathrm{kg})\end{array}$ & 22.3 & $16.5-17.5$ \\
\hline
\end{tabular}

In general, density and viscosity of pyrolysis oil produced is lower than pyrolysis oil as reported [8]. This result is good because it will be an advantaged on storage and distribution of pyrolysis oil. But acidity is higher, which indicated that oil produced contains many compounds which were reflected acid characters and caused corrosion on storage materials. It is recommended for storage used stainless steel materials and materials derived from the olefin polymer [8].

Physical properties from several run from this study is presented in Table 2 as followed.

Table 2 : Physical characteristics of Pyrolysis oil of Terminalia catappa

\begin{tabular}{|c|c|c|c|c|c|}
\hline \multirow{2}{*}{$\begin{array}{c}\text { Metal } \\
\text { load }\end{array}$} & RWCB & $\begin{array}{c}\text { Density } \\
(\text { gram/ml })\end{array}$ & $\begin{array}{c}\text { Viscosity } \\
(\mathrm{cSt})\end{array}$ & $\begin{array}{c}\text { Acid } \\
\text { number (mg } \\
\text { NaOH/gram } \\
\text { pyrolysis oil } \\
)\end{array}$ & $\begin{array}{c}\text { Heating } \\
\text { Value } \\
(\mathrm{MJ} / \mathrm{kg})\end{array}$ \\
\hline \multirow{3}{*}{$0 \%$} & $2 \%$ & 0.861 & 7.872 & 73.211 & $\mathrm{NA}$ \\
\cline { 2 - 6 } & $4 \%$ & 0.836 & 7.975 & 68.692 & 42.588 \\
\cline { 2 - 6 } & $6 \%$ & 0.864 & 8.128 & 75.923 & $\mathrm{NA}$ \\
\hline \multirow{3}{*}{$1 \%$} & $2 \%$ & 0.797 & 7.807 & 62.365 & $\mathrm{NA}$ \\
\cline { 2 - 6 } & $4 \%$ & 0.762 & 7.563 & 61.913 & $\mathrm{NA}$ \\
\cline { 2 - 6 } & $6 \%$ & 0.815 & 6.536 & 91.288 & $\mathrm{NA}$ \\
\hline \multirow{3}{*}{$1,5 \%$} & $2 \%$ & 0.802 & 9.189 & 83.154 & $\mathrm{NA}$ \\
\cline { 2 - 6 } & $4 \%$ & 0.783 & 9.096 & 93.096 & $\mathrm{NA}$ \\
\cline { 2 - 6 } & $6 \%$ & 0.726 & 6.389 & 87.673 & $\mathrm{NA}$ \\
\hline \multirow{3}{*}{$2 \%$} & $2 \%$ & 0.817 & 6.206 & 59.654 & 43.293 \\
\cline { 2 - 6 } & $4 \%$ & 0.758 & 7.073 & 61.461 & 44.387 \\
\cline { 2 - 6 } & $6 \%$ & 0.851 & 6.812 & 70.500 & 44.564 \\
\hline
\end{tabular}

NA: not available

Density is seemed in range $0.758-9.189 \mathrm{cSt}$ having average of 0.806 which is in a range similar to reported by reseacher elsewhere [8]. Acid number ranged of 59.654-93.096 $\mathrm{mg} /$ gram of pyrolysis oil which is too high compared to result revealed elsewhere [8]. Overall, pyrolysis oil produced from this study has potential to be further developed as an alternative fuel having some further treatments to improve its physical properties as well as heating value.

\subsubsection{Analysis of Chemical compunds of Pyrolysis oil}

Chemical analysis carried out using Gas ChromatographyMass Spectrometry (GC-MS) was aimed to determine compounds its contained. Compounds of decomposition of cellulose, hemicellulose and lignin contained in pyrolysis oil using catalysts Ni/NZA having nickel metal content of $2 \%$, RWCB 4\% were subjected of measurement. There are several peaks response of compounds were detected and five among their dominant compounds were identified as acetic acid, 2propanone, 1,2-ethanediol, propionic acid and methyl acetate having area of $60.84,12.64,8.60,5.60$ and $3.76 \%$ respectively. From literature elsewhere [11] revealed that pyrolysis oil contained phenol of more than $50 \%$ would be very good used as fuel. But in this study, it seemed no phenolic compounds found in either pyrolysis oil produced from pyrolysis process without or with a nickel metal catalyst. This is probably due to pyrolysis temperature used of $320^{\circ} \mathrm{C}$ which most of the lignin in woody biomass might has not been decomposed. This result is related to report elsewhere [12], revealed that formation of phenolic compounds as decomposition of lignin in biomass occured over a temperature range of $400-500^{\circ} \mathrm{C}$. 


\section{International Journal of Science and Research (IJSR) \\ ISSN (Online): 2319-7064}

Index Copernicus Value (2013): 6.14 | Impact Factor (2015): 6.391

\section{Conclusion}

Based on result and discussion session has previously revealed it could be concluded as followed.

- Thermal conversions of wood Terminalia catappa using catalytic pyrolysis of $\mathrm{Ni} / \mathrm{NZA}$ have proven produce pyrolysis oil that can be used as an alternative energy.

- The more amount catalyst Ni/NZA used in pyrolysis process will produce more pyrolysis oil. The highest pyrolysis oil produced given by $\mathrm{Ni} / \mathrm{NZA}$ to biomass ratio, RWCB 4\%, having $2 \%$ metal Ni, having yield $68.22 \%$.

- On the other hand the lowest level is given by Ni/NZA to biomass ratio, RWCB 2\% having no metal content, which is $44.77 \%$.

- Based on physical characteristics of pyrolysis oil produced it has density $0.806 \mathrm{~g} / \mathrm{ml}$, viscosity $7.591 \mathrm{cSt}$, acidity $74.078 \mathrm{mg} \mathrm{NaOH} /$ gram and calorific value of 43.708 $\mathrm{MJ} / \mathrm{kg}$ respectively.

- Several compounds were detected by GC-MS measurement which among them are five dominant compounds indentified as acetic acid, 2-propanone, 1, 2-ethanediol, propionic acid and methyl acetate respectively.

\section{Acknowledgment}

Author would like to pay gratitude Universitas Riau for funding this work. Many thanks addressed to Laboratory of Organic Chemistry of the UGM for assistances.

\section{References}

[1] Detrina, I., Yusnitawati, Syaiful, B. and Edy, S., Kajian Pyrolysis oil Dari Limbah Padat Sawit Dengan Metoda Fast Pyrolysis. In Proceding of Seminar Nasional Teknik Kimia Teknologi Oleo dan Petrokimia Indonesia, 2006.

[2] Thomson, L. A. J. and B. Evans, Terminalia Catappa (Tropical Almond) Combretaceae (Combretum Family). Jurnal Species Profiles for Pacific Island Agroforestry 2(1), pp. 1-17, 2006.

[3] Goyal, H.B., Diptendu, S. and Saxena, R.C., Bio-Fuels from Thermochemical Conversion of Renewable Resources: A Review. India Institute of petroleum. India, 2006.

[4] Trisunaryanti, W., Endang, T. dan Sri, S. Preparasi. Modifikasi dan Karakterisasi Katalis Ni-Mo/Zeolit Alam dan Mo-Ni/Zeolit Alam. Jurnal TEKNO IN 10(4), pp. 269-282, 2005.

[5] Setyawan, D. dan Handoko, P., Preparasi Katalis $\mathrm{Cr} /$ Zeolit Melalui Modifikasi Zeolit Alam. Jurnal Ilmu Dasar, Vol. 3 No.1, pp.15-23, 2002

[6] Lestari, D.Y. dan Triyono, Hidrogenasi Katalitik Metil Oleat Menggunakan Katalis Ni/Zeolit dan Reaktor Sistem Fixed Bed. Jurusan Kimia. Universitas Gadjah Mada, 2010

[7] Sunarno dan Silvia, R.Y., Pembuatan Zeolit Sintetis dan Aplikasinya Sebagai Katalis pada Cracking Cangkang Sawit Menjadi Pyrolysis oil. Jurnal Teknobiologi, IV(1) 2013: 35- 39: ISSN, pp. 2087-5428, 2013.
[8] Mohan, D., Charles, U.P. and Philip, H.S. Pyrolysis of Wood/Biomass for Pyrolysis oil: A Critical Review. Jurnal Energy \& Fuels 20, pp. 848-889, 2006.

[9] Smallwod, Hydroprocesing of Pyrolisis oil to Fuel and Chemical. Pacific Northwest National Laboratory U.S. Departemant of Energy, 2008.

[10]Lehto, J., Oasma, A., Solantausta, Y., Kyto, M. \& Chiaramonti, D. Fuel Oil Quality and combustion of Fast Pyrolysis Bio-Oils. Finlandia: VTT Technical Research Centre of Finland, 2013.

[11]BTG, Bio-oil Applications, 2003. Retrieved January 24, 2014, http://www.btgword.com.

[12] De Wild, P.J., Reith, H \& Heeres, H.J. Biomass Pyrolysis for Chemicals (Chapter 1), Biofuels. 2 (2), pp. 185-208, 2011 